\title{
JUDICIAL IMPARTIALITY IN AN EMPIRICAL ERA
}

\author{
Tigran W. Eldred*
}

The psychological dimensions of judicial impartiality is a topic of considerable interest, with a growing body of scholarship focused on the reasons judges often are unable to perceive their own biases. ${ }^{1}$ The attention is not on why judges intentionally downplay factors that can undermine their own objectivity, but rather on the empirical reasons that everyone, judges included, tend to be unaware of the impact of their own biases. This "bias blind spot," 2 a product of a series of unconscious cognitive and motivational factors, is at the center of the discussion, with even the Supreme Court making passing reference to the pernicious influence of unconscious psychological factors in its recent disqualification jurisprudence. ${ }^{3}$

Professor Robertson's article, Judicial Impartiality in a Partisan $E r a,{ }^{4}$ makes a significant contribution to this topic by deftly integrating the psychology of judicial decision-making into the larger conversation about the partisan threat, real and perceived, to judicial impartiality. Her analysis emphasizes the psychological dimensions of identity theory, a

* Professor of Law, New England Law | Boston. Many thanks to my colleague, Jordan Singer, for his helpful comments on this response.

1. See., e.g., Debra Lyn Bassett, Three Reasons Why the Challenged Judge Should Not Rule on a Judicial Recusal Motion, 18 N.Y.U. J. LeGIS. \& PUB. PoL'y 659, 659-60 (2015); Debra Lyn Bassett \& Rex R. Perschbacher, The Elusive Goal of Impartiality, 97 IowA L. REv. 181, 184 (2011); Melinda A. Marbes, Reshaping Recusal Procedures: Eliminating Decisionmaker Bias and Promoting Public Confidence, 49 VAL. U. L. ReV. 807, 809-10 (2015) [hereinafter Reshaping Recusal]; Melinda A. Marbes, Refocusing Recusals: How the Bias Blindspot Affects Disqualification Disputes and Should Reshape Recusal Reform, 32 ST. LouIS U. Pub. L. Rev. 235, 237 (2013) [hereinafter Bias Blindspot]; W. Bradley Wendel, Campaign Contributions and Risk-Avoidance Rules in Judicial Ethics, 67 DePaul L. Rev. 255, 255 (2018).

2. Bassett, supra note 1, at 670-71; Bias Blindspot, supra note 1, at 249; Wendel, supra note 1 , at 255 .

3. See, e.g., Williams v. Pennsylvania, 136 S. Ct. 1899, 1906 (2016) ("There is . . a risk that the judge 'would be so psychologically wedded' to his or her previous position as a prosecutor that the judge 'would consciously or unconsciously avoid the appearance of having erred or changed position."') (citation omitted); Caperton v. A.T. Massey Coal Co., 556 U.S. 868, 883-84 (2009) ("In defining [the constitutional] standards [for recusal], the Court has asked whether, 'under a realistic appraisal of psychological tendencies and human weakness,' the interest 'poses such a risk of actual bias or prejudgment that the practice must be forbidden if the guarantee of due process is to be adequately implemented."') (citation omitted). For a discussion of how the Supreme Court has missed an opportunity to cite scientific authority for these observations, see Tigran W. Eldred, The Psychology of Conflicts of Interest in Williams v. Pennsylvania, New Eng. L. Rev. FAculty Blog (June 20, 2016), https://newenglrev.com/2016/06/20/faculty-blog-the-psychology-of-conflicts-of-interest-inwilliams-v-pennsylvania/ [https://perma.cc/N83W-SK8X].

4. Cassandra Burke Robertson, Judicial Impartiality in a Partisan Era, 70 Fla. L. Rev. 739 (2018). 
field of study that explores how people behave based on the social groups to which they belong. ${ }^{5}$ As she explains, judicial identity is closely wrapped in the self-perception of impartiality, the foundational feature of the rule of law, so that any non-verifying feedback threatening that identity can be expected to produce "emotional distress and a tendency to employ cognitive strategies that discount or discredit such feedback." 6 The bias blind spot is one such cognitive response, which allows judges to maintain a belief in their own objectivity, even when there is evidence to the contrary. ${ }^{7}$ Partisanship, like all motivations, can do its work without any conscious awareness of its deleterious effects. ${ }^{8}$

Professor Robertson also makes the compelling argument that recusal is a weak tool to protect against the appearance of judicial bias for a number of reasons, including the malleability of determining how a reasonable person might perceive the effects of a judge's partisan leanings. ${ }^{9}$ As she states:

The appearance of impartiality, after all, is in the eye of the "reasonable" beholder-and as the public grows more partisan, views of judicial conduct will likewise split along party lines. ... When the public is so polarized, it becomes extremely difficult to identify the view of a "reasonable" person. ${ }^{10}$

Indeed, she notes that allegations of partisan bias may even do more harm than good by further undermining public confidence in an impartial judiciary. ${ }^{11}$

As with any strong analysis based on empirical claims, Professor Robertson's article raises additional questions to be explored. To begin with is the extent and scope of judicial partisan bias, a topic of vast exploration among legal academics, political scientists, and others. ${ }^{12}$ The near consensus of most research is that political orientation of judges often matters in judicial decisions-reinforcing the belief of

5. See id. at 746-51.

6. Id. at 760 .

7. See id. at $749,762-63$.

8. See Ziva Kunda, The Case for Motivated Reasoning, 108 Psychol. Bull. 480, 480 (1990) (discussing the power of motivated reasoning).

9. See Robertson, supra note 4, at 768.

10. Robertson, supra note 4, at 768-69.

11. Id. at 769 .

12. See Jeffrey J. Rachlinski et al., Judicial Politics and Decisionmaking: A New Approach, 70 VAND. L. Rev. 2051, 2052, 2055 (2017). 
some critics that judges are merely "politicians in robes." 13 If so, then Professor Robertson's project is all the more important, as it addresses fundamental questions and proposes solutions to threats to the foundation of democratic legitimacy.

But what if political orientation is less powerful a factor in judicialdecision making than conventional wisdom suggests? A number of recent re-assessments of the role of judicial partisanship raise this possibility. ${ }^{14}$ For instance, researchers who have done much of the ground-breaking work on the psychology of judicial decision-making question the methodology of almost all of the relevant research, which narrowly focuses on assessing partisan bias by reviewing and parsing judicial decisions rather than by using experimental design. ${ }^{15}$ The problem with this approach, they note, is that drawing inferences about the effects of political ideology from single decisions has inherent limitations given the wide variability of circumstances between cases. ${ }^{16}$ Analysis of multi-member courts, including the Supreme Court, attempt to address this problem by combining cases for assessment, but this can result in errors that are very difficult to control for in statistical analysis. ${ }^{17}$ Other experts in the psychology of decision-making have made similar critiques, noting many of the limits posed by research that does not employ experimental design to study behavior of actual judges. ${ }^{18}$ The bottom line of these critiques is that, even if certain statistical formulas point towards findings of extensive partisan bias in how judges render decisions, the actual evidence of such bias is difficult to document.

But there is more: in an effort to move away from the methodological problems of the past, researchers have started to conduct experimental studies in an effort to determine the extent of partisan bias in judicial decision-making. ${ }^{19}$ And the results complicate conventional wisdom. For example, a series of twenty-five controlled

13. Id. at 2051-53; see also Lee Epstein \& Jack Knight, Reconsidering Judicial Preferences, 16 ANN. ReV. POL. SCI. 11, 14 (2013) (“Among political scientists, not only is it uncontroversial to say that judges seek to etch their political values into law-it would be near heresy to suggest otherwise.").

14. See, e.g., Rachlinski et al., supra note 12, at 2055.

15. See id.

16. Id.

17. See id. at 2055-56. Interestingly, two of the authors reporting these studies have stated elsewhere that they "accept the conclusion that judges are political actors whose beliefs influence their judgment.” Jeffrey J. Rachlinski \& Andrew J. Wistrich, Judging the Judiciary by the Numbers: Empirical Research on Judges, 13 AnN. REV. LAw Soc. ScI. 1, 5 (2017).

18. See Dan M. Kahan et al., "Ideology" or "Situation Sense"? An Experimental Investigation of Motivated Reasoning and Professional Judgment, 164 U. PA. L. REV. 349, 41012 (2016).

19. See, e.g., Rachlinski et al., supra note 12, at 2051. 
experiments of over 2,200 judges (mostly from trial courts) conducted over nearly twenty years reveal that "political attitudes have exhibited a weak effect on judicial decision-making." 20 Significantly, the fact patterns in the studies - which involve a wide range of subjects, including bankruptcy, criminal law, and certain civil cases-are salient in that they implicate politics in meaningful ways. ${ }^{21}$ In another experimental study of actual judges, a set of leading researchers focused on the effects of motivated cultural cognition on judicial decisionmaking, with results that were "strongly at odds with the conclusion that judges are influenced by political predispositions when they engage in legal reasoning." 22 The researchers attributed these findings to a type of "situation sense" produced by professional training and experience that helps to immunize judges from extraneous factors such as ideological predispositions when deciding cases. ${ }^{23}$ While it is premature for any firm conclusions from these studies, they do raise important questions and the need for further experimental study about the extent to which political bias affects judicial decision-making.

The possibility that partisan affiliation matters less to judges than previously thought also opens the door to many other perspectives in assessing judicial behavior. For instance, two leading scholars have recently called upon the political science community to recast their efforts from the almost exclusive focus on judicial policy preferences toward the wider web of motivations that have been identified as relevant to how judges make decisions. ${ }^{24}$ Organized into five overarching categories, these motivations include job satisfaction, external satisfactions, leisure, salary/income, and promotion. ${ }^{25}$ Other relevant considerations may include the personal demographic characteristics of judges, which tend to matter in salient situations. ${ }^{26}$ Then there is the growing body of empirical research into the unconscious, emotional, and intuitive factors that can influence and bias the judicial mind..$^{27}$ Many studies, for instance, have documented the role of heuristics and cognitive biases in judicial decision-making, including confirmation bias, hindsight bias, anchoring, and framing

20. Id. at 2097.

21. Id. at 2058.

22. Kahan et al., supra note 18 , at 354 .

23. Id. at 354-55.

24. Epstein \& Knight, supra note 13, 12-13.

25. Id. at 19 .

26. Rachlinski \& Wistrich, supra note 17, at 5 ("[D]emographic characteristics-e.g., religion, gender, race, and past employment-all influence judges. The influence of demographics follows a predictable pattern: Judges tend to decide cases that present issues salient to their demographic characteristics in ways that favor their demographic profile.").

27. See id. at 9-14. 
effects, to name just a few. ${ }^{28}$ Together, these and other avenues of research will continue to help mold a realistic, three-dimensional view of judicial decision-making that, as one author has noted, will move past the dichotomous focus on whether policy preferences of judges do, or do not, predict case outcomes. ${ }^{29}$

Professor Robertson's recommendation that judicial impartiality is best protected by mechanisms other than weak recusal rules is well suited for this rich empirical environment. Even if the results of future research downgrades the importance of politics in judicial decisionmaking, the growing partisan divide in the country suggests there will be no shortage of claims that judges appear to be, if not actually are, politicians in robes. Curbing judicial discretion through the types of remedies she identifies - such as brighter line rules and the emerging idea of some form of preemptory challenges for judges in appearance cases - can, as she notes, help "ameliorate the perception of political bias in the judiciary." 30 And the procedural safeguards that she cites, including the jury process and the accountability effects of appellate review, can be important to counteract those instances where judicial partisan bias rears its head. ${ }^{31}$

To these I would add two more. First, as long as judges tie their social identity to the ideal of judicial impartiality, any allegations of bias - whether based on partisanship or otherwise - can be expected to produce the type of non-verifying feedback that Professor Robertson has described. The point here is not that bias will go undetected (it may or may not), but rather that judges, like the rest of us, are poorly equipped to make accurate self-assessments of their own objectivity. As a result, and as Professor Robertson notes, this has led some commentators to argue that the judge, against whom bias is alleged, not be the sole arbiter of whether recusal is warranted. ${ }^{32}$ This sensible approach to reducing the power of the bias blind spot, both on actual and perceived bias, would need to take into account any potential adverse effects, including risks to collegiality between members of the bench who might be called upon to render judgments about each other's impartiality. ${ }^{33}$ Second, if it turns out, as preliminary research suggests, ${ }^{34}$ that judges are less influenced by partisanship than has been generally

28. See id. at 18-19, 23, 26.

29. See Charles Gardner Geyh, Can the Rule of Law Survive Judicial Politics?, 97 CORNELl L. REV. 191, 211-14 (2012).

30. Robertson, supra note 4 , at 772 .

31. Id. at 772-73. For studies discussing the role of appellate review as an accountability mechanism for judicial decision-making, see Rachlinski \& Wistrich, supra note 17, at 9-11.

32. Robertson, supra note 4, at 765 n.167.

33. For further discussion of such options, see Reshaping Recusal, supra note 1, at 84952.

34. See supra notes 16-19 and accompanying text. 
believed, then educating the public about that result should be a top priority. ${ }^{35}$ Indeed, it may be that one of the biggest threats caused by public perceptions of judicial partisan bias is the faulty empirical premise upon which it rests.

35. I do not suggest this task will be easy, as it must overcome what has been called the "Neutrality Communication Problem," namely identifying ways to overcome the public's perception of judicial partiality in cases where cultural anxiety is expected to be significant. See Kahan et al., supra note 18, at 419-22. 